\title{
EL PERSONAJE DE LA INTERMEDIARIA EN LA LITERATURA HEBREA MEDIEVAL ESCRITA EN SEFARAD
}

MARTA SARA FORTEZA-REY

La intermediaria entre dos jóvenes de sexo opuesto aparece como personaje literario en varias creaciones medievales escritas en suelo peninsular.

La intención de nuestro artículo es presentar las apariciones y las características de este personaje en la literatura hebrea medieval.

En el mundo judío la intermediaria es la casamentera (šadkanît). Según nos indica el diccionario hebreo es la persona cuyo trabajo consiste en mediar entre hombre y mujer con la finalidad de casarlos '.

Sin embargo, durante la Edad Media, existieron otras versiones de la intermediaria: la árabe ${ }^{2}$, la castellana ${ }^{3}$, la catalana ${ }^{4}$, etc., tantas como culturas se desarrollaron en la Península. Todas ellas apuntan hacia la definición de alcahueta: persona que solicita por cuenta de otro a una mujer con fines lascivos o persona que concierta o encubre amores ilícitos.

Como puede apreciarse, la diferencia entre casamentera y alca-

1 A pesar de que este trabajo puede ser desempeñado tanto por el hombre como por la mujer, los tres casos que presentamos aquí, son de mujeres. Éste es el motivo por el que nos referiremos siempre al personaje como femenino. Cf. A Complete Dictionary of Ancient and Modern Hebrew [heb.] by Eliezer BEN YeHUDA. Jerusalem 1952, vol. XIV, p. 6914, y אברחם אבן־שושן Jerusalem 1970, vol. VII, p. 2621.

${ }^{2}$ El vocablo árabe al-qawwad hace referencia a la persona encargada de llevar un regalo de parte de su amo, como medio de captar la simpatía del marido y así poder llegar a su mujer.

${ }^{3}$ En el reino de Castilla se conoce a la intermediaria por el nombre de alcahueta. En su literatura son conocidos los nombres de Trotaconventos y Celestina.

${ }^{4}$ En el condado de Cataluña la intermediaria recibe el nombre de Arcabot o Alcabot. 
hueta radica en la finalidad que persiguen. Sin embargo, los medios que ambas utilizan en su trabajo de mediar, son parecidos.

Nos interesan aquí concretamente las descripciones del aspecto y la conducta de la intermediaria hasta que consigue su fin.

De la literatura producida por las tres comunidades que coexistieron en la Península Ibérica durante la Edad Media, éstas son las variedades más relevantes registradas del personaje de la intermediaria:

1. La mensajera como mero instrumento que posibilita la comunicación entre los amantes.

2. El mensajero que seduce a la amada de quien le envía.

3. La mujer-diablo que disfruta separando un feliz matrimonio por medio de falsos mensajes.

4. La vieja que engaña a una joven esposa para entregarla a otro hombre.

5. La mujer que promete una hermosa doncella a un joven y el día de la boda se la cambia por una fea.

6. La vieja que, a cambio de dinero, ayuda a un joven a seducir a la mujer que desea, con la que después se casa.

7. La vieja que ayuda a un joven a seducir a la mujer que desea y que después encubre sus relaciones a cambio de dinero.

La primera variedad aparece en el capítulo noveno de la obra árabe de Ibn Hazm, El collar de la paloma s. La segunda aparece en el capítulo veintitrés de la misma obra y es el caso de Fernando Garcia, mensajero del Arcipreste de Hita ${ }^{6}$.

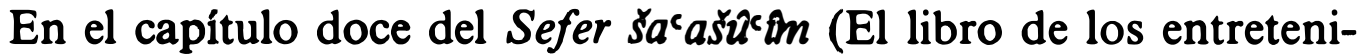
mientos) de Yosef ben Meir ben Zabarra 7 y en el ejemplo cuarenta

5 Véase la traducción castellana de E. García Gómez, El Collar de la Paloma de Ibn Hazm de Córdoba, Madrid 1952. Se trata de una recopilación en prosa de anécdotas, relatos y experiencias, con intercalación de versos que reafirman lo anteriormente narrado. El capítulo nueve está dedicado al mensajero. En él, el autor (991-1063) nos describe a un personaje con detalles concretos: mujeres con báculo, rosarios y los dos vestidos encarnados. Su virtud más preciada es la de no levantar sospechas y con esta finalidad se ocupan en varios oficios: curandera, aplicadora de ventosas, vendedora ambulante, corredora de objetos, hilandera, tejedora, cantora, maestra de canto, mandadera, peinadora, plañidera o echadora de cartas. En el capítulo veintitrés, se nos describe la traición de un mensajero varón.

6 Cf. M. Nicasio Salvador, El Libro del Buen Amor de Juan Ruiz, Arcipreste de Hita, Madrid 1984.

7 Cf. י. Tאווידזאן, ספר שעשועים לרי וסף בן מאיר בן זבארת New York 1914, y M. S. ForTEZA-REY, El Libro de los entretenimientos de Yosef Zabarra, Madrid 1983. 
y dos del Conde Lucanor de Don Juan Manuel está incluido el tercer modelo ${ }^{8}$.

La cuarta variedad aparece en la obra latina de Pedro Alfonso, Disciplina Clericalis ${ }^{9}$, y en el Libro de los engannos e assayamientos de las mugeres ${ }^{10}$.

El quinto modelo de intermediaria aparece en dos obras hebreas: Minhạ Y Yěhûdâ, śône ha-našîm (La ofrenda de Yehudah, el que odia a las mujeres) de Yehudah ben Sabbatay "y Tahkěmônî (El sabio) de Al-Harizi ${ }^{12}$.

La sexta variación corresponde a Trotaconventos ${ }^{13}$ y la séptima a La Celestina ${ }^{14}$.

Entre todas estas obras, sólo tres están escritas en lengua hebrea: La ofrenda de Yehudah, el que odia a las mujeres, El libro de los entretenimientos y El sabio. Las tres tienen en común su carácter laico y lúdico, su relación con la maqama árabe, el hecho de que la intermediaria aparezca como un personaje secundario y el haber

${ }^{8}$ Con relación a la aparición de este tipo de intermediaria en otras obras, véase R. Ayerbe-ChauX, El Conde Lucanor: Material tradicional y originalidad creadora, Madrid 1975, pp. 13-20 y 334-350.

${ }^{9}$ Pedro Alfonso era un estudioso judío de Huesca (1062-1110) que se convirtió al cristianismo. Antes de su conversión era conocido como el rabino Moseh Sefardi. .Hombre capaz de escribir en árabe, hebreo, latín o romance. Cf. R. E. MARSAN, Itinéraire espagnol du conte médiéval, Paris 1973, p. 113. Disciplina Clericalis es una colección de ejemplos que tienen todos ellos una finalidad didáctica y moralista. La intermediaria aparece en el ejemplo trece: Exemplum de canicula lacrimente. Véase la edición y traducción de A. GonzÁlez Palencia, Madrid-Granada 1948, pp. 32-34 y 126-129.

${ }^{10}$ Se trata de la traducción del Sendebar, que en el año 1235 encargó el Infante don Fadrique, hermano de Alfonso el Sabio. Nos referimos aquí al décimo ejemplo: Enxemplo del omme e de la muger e de la vieja e de la perrilla. Véase A. GonZÁLEZ Palencia, Versiones castellanas de Sendebar, Madrid 1946. 1-24.

$"$ Cf. א.מ. חברמן, שלוש מקאמות על הנשים מחן בגנותן ומחן בשבחו, Jerusalem 1971, pp.

12 Cf. י. Tופורובסקי, רבי יחודת אלחריקי : תחכמוני Thiv 1952. En la quinta variedad habría que incluir el modelo de intermediaria que aparece en la obra latina De vetula, escrita durante la segunda mitad del siglo XIII. La obra fue muy leída pero no está claro si fue escrita en la Península Ibérica. Cf. F. Rico, «El origen de la autobiografía en el Libro de Buen Amor", Anuario de Estudios Medievales 4 (1967) pp. 311-312.

${ }^{13}$ En esta variedad habría que incluir a la intermediaria de la obra latina Pamphilus que circuló por la Península Ibérica pero fue escrita en Francia. Véase G. CoHEN, La comédie latine en France au XIIe siècle, vol. II, Paris 1931.

${ }^{14}$ Cf. M. Criado de VAl y G. D. Trotter, Tragicomedia de Calixto y Melibea, 2." ed., Madrid 1965. 
sido escritas entre finales del siglo XII y la primera mitad del siglo XIII.

A continuación presentamos los tres modelos de intermediaria contenidos en las obras mencionadas.

En el año 1188, el médico judío Yehudah ben Isaac ibn Šabbatay escribe en lengua hebrea la primera versión de su obra La ofrenda de Yehudah, el que odia a las mujeres. La escribe en prosa rimada e intercala versos y citas bíblicas dentro del texto, según el estilo del género que desarrollaron los árabes: la maqama. Sólo el hecho de ser un relato continuo desde el principio hasta el fin y no escrito en capítulos independientes, nos impide incluirlo dentro de la forma clásica de este género ${ }^{15}$.

El autor dedica la segunda versión de su obra en el año 1208 a Abraham Al-Fakar, cortesano del rey Alfonso VIII de Castilla.

Sus fuentes de inspiración fueron:

1. La Biblia: El Cantar de los Cantares y el relato bíblico de Raquel y Leah.

2. La literatura árabe: Las mil y unas noches, las Maqamas de Al-Hamadani y un relato parecido, escrito en el siglo XI y atribuido a Ibn Al-Sirag ${ }^{16}$.

La obra está escrita al estilo paródico, en ella se mezclan la imaginación y la realidad con el humor ${ }^{17}$.

Tậkěmonî (sabio) es un hombre anciano que tuvo una mala experiencia matrimonial y esto influyó tanto en él, que no hace más que sermonear a su único hijo Zerah (esplendor), sobre la maldad de la mujer y le recomienda no casarse con ninguna. El hijo asume las palabras de su padre y decide no casarse nunca, convencido de que todos los problemas de los hombres son debidos a las mujeres. Otros misóginos se reúnen con Zerah y deciden vivir aislados en régimen de camaradería.

Pero las mujeres, preocupadas por su futuro, se reúnen para tomar medidas contra Zerah y su proyecto. $\mathrm{Y}$ aquí aparece nuestro

${ }^{15}$ Cf. D. Pagis, Change and Tradition in the Secular Poetry: Spain and Italy [heb.], Jerusalem 1976, pp. 219-220.

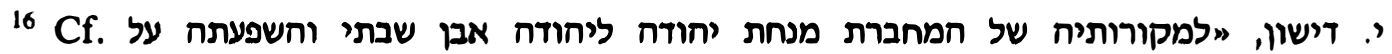
מקאמת חנישואין ליחודח אלחריוים, Tesoro de los judios sefardies XI-XII (1969-1970) pp. 57-73.

17 Cf. I. Davidson, Parody in Jewish Literature, New York 1907, pp. 7-11. 
personaje Kozbî (mi engaño) ${ }^{18}$. Al principio más que una intermediaria, parece una feminista preparando su ataque contra los hombres:

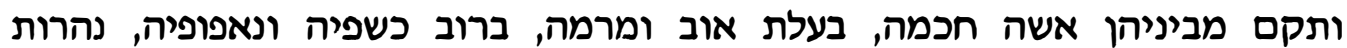
לא ישטפו רשפיה, ושמה כזבי בת ירשה י', כי כי אחזה התרמית במרת למורשה, ולה איש זקן

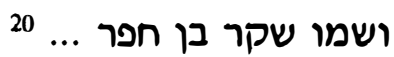

Y se levantó entre ellas una mujer sabia, hechicera y falsa por cuyos muchos sortilegios y fornicaciones, ni los ríos podrán anegar sus llamaradas. Y su nombre era Kozb̂̀ bat Yĕresâ, porque tiene el engaño en propiedad. Tenía un marido anciano de nombres Šeqer ben Hefer [mentira, hijo de la fosa]...

ועתה אחיותי ורעיותי, אלה מועצותי, ואלה מזמותי: נשים העלמה לנגדו והזהב

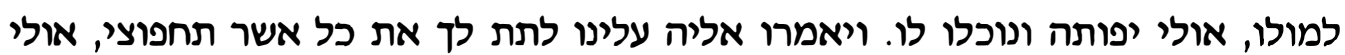
תוכלי אולי תערוצי ופולי ונכלו יפולו

Y ahora, hermanas y compañeras mías, éstas son mis propuestas y mis proyectos: pondremos ante él la doncella y el oro, quizás será seducido y le venceremos. Y le respondieron: Aceptamos darte todo lo que desees.

Kozbî reúne dinero para los gastos del proyecto y elige una muchacha muy hermosa, inocente y culta, justo el tipo de mujer que puede gustar a Zerah. Entonces salen todas las mujeres acompañadas de Šeqer, al encuentro de Zerah.

La primera reunión entre Kozbî y Zerah tiene las características de una disputa pública. Kozbî expone, con gran conocimiento de las Escrituras y con gran sabiduría, que la forma de vida escogida por Zerah no es natural ni del agrado de Dios. Zerah responde atacando personalmente a Kozbí y entonces ésta se da cuenta de que el éxito es probable:

יאריך אלהים שלותך, כל הימים על אדמתך, ארץ ממנה יצא לחם, וכמוך יצא מרחם.

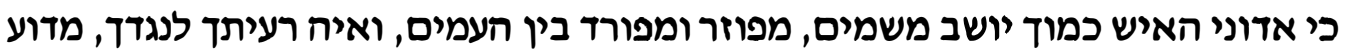
אתה יושב לבדך, ואיך יעלה על משמי מקומך שמיר ושית, תפארת אדם לשבת בית בית, הלא מדא

${ }^{18}$ El nombre aparece en Num 25,15 . Hay que señalar el juego de palabras que hace el autor con el significado de la palabra en hebreo. Así nos insinúa la poca fiabilidad del personaje.

${ }^{19}$ Nombre paralelo a Kozbî bat Sûr que aparece en Num 25,15.

20 א.מ. op. cit., p. 9.

21 א.מ. הברמן חברמן, ibid., p. 10. 


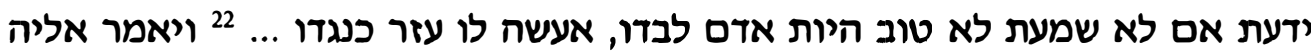

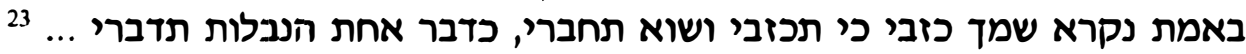

Que Dios alargue tu bienestar todos los días que estés en la tierra de la que sale el pan, que como tú sale de las entrañas. ¡Por Dios! ¿Por qué un hombre como tú está aturdido, disperso y separado de los pueblos? ¿Dónde está tu compañera? ¿Por qué estás solo? ¡Cómo invadirán la zarza y el espino tu lugar, hombre bello, para que habite en una casa! ¿Es que no sabes, ni oíste, que no es bueno que el hombre esté solo? Yo le daré una ayuda adecuada ... Y le contestó: Con razón te llaman Kozbî, porque mientes, compones embustes y dices majaderías...

וכזבי שומעת אחר הדלת והמזוזה, כי דבר הי בזה ... ותאמר בלבה הנה זרח

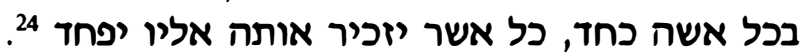

Y Kozbî escuchaba detrás de la puerta y de la jamba, porque las palabras de Dios están en ella ... Y se dijo a sí misma: he aquí que Zerah reniega de toda mujer y le asusta todo lo que se la recuerda.

Sin embargo, cuando ve a la muchacha que Kozbî ha elegido para él, su actitud con ella va cambiando en medio de contradicciones internas. Como ella esperaba, su naturaleza se impone.

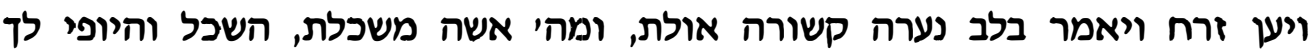

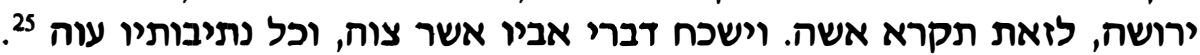

Respondió Zerah̆ y dijo: relacionada está la muchacha con la tontería, pero la mujer es inteligente debido a Dios y la sabiduría y belleza tienes en heredad. ¡Ésta será llamada mujer! Y olvidó las palabras de su padre y todos sus caminos torció.

Ahora Zerah busca a Šeqer y Kozbi porque quiere casarse con la muchacha y quiere firmar el contrato matrimonial ante testigos. El texto de la $K \ddot{t} t u b b \hat{a}$, que es leído en la ceremonia, es una auténtica parodia. Según es costumbre aceptada, en él aparece el nombre de la novia, un nombre que nos produce cierta inquietud:

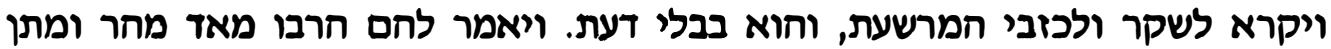

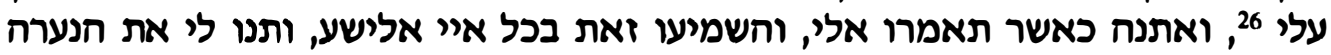

\section{הזאת לאשה עלי ואתנח}

\footnotetext{
$22 \mathrm{Gn} 2,18$.

${ }^{23}$ א.א. op. cit., p. 12.

24 א.א. op. cit., p. 13.

25 , op. cit., p. 14.

26 Cf. Gn 34,12.

27 א.א. op. cit., p. 16.
} 
Llamó a Šeqer y a la malvada Kozbî y sin saber lo que hacía les dijo: Pedidme cualquier dote, por grande que sea, que yo os daré cuanto me digáis. Anunciadlo por todas partes y dadme a la muchacha por mujer.

Kozbî se apresura a anunciar el éxito de la empresa a las demás doncellas y así les dice en la Colina de los Prepucios ${ }^{28}$ :

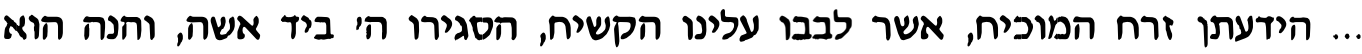
לחרפה ובושה. נתן אלהים בידינו, את זרח אויבינו 29.

... Es que no sabéis que a Zeraḥ, el censor que endureció su corazón contra nosotras, lo ha entregado Dios en manos de una mujer, cayendo en el oprobio y la vergüenza. Puso Dios en nuestras manos a Zerah, nuestro enemigo.

Y cuando se terminó la ceremonia de la firma del contrato,

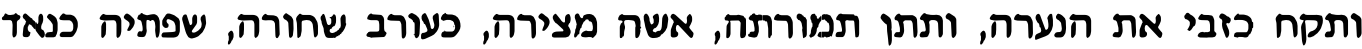

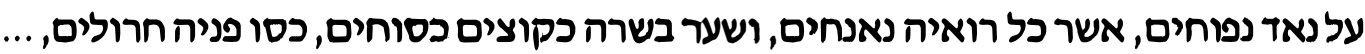

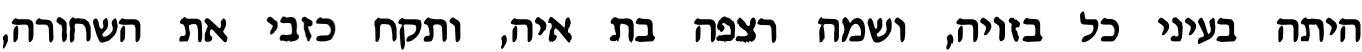

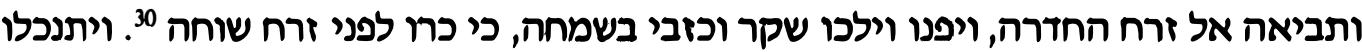

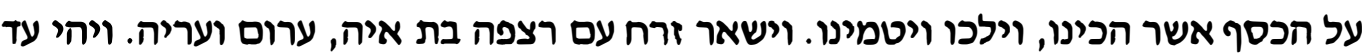
כה ועד כה, ויזרח לו חשמש והפוא צולע ולע על ירכו. וחנה רצפה מקרם אילה שלוחה... 31

Cogió Kozbî a la muchacha y la cambió por una mujer doliente, negra como un cuervo, sus labios eran como un pellejo sobre un odre hinchado, todo el que la viera suspiraría. El vello de su cuerpo era como zarzas cortadas y espinas cubrían su rostro ... despreciada a los de ojos de todos y su nombre era Rispa bat 'Aya [suelo, hija del buitre]. Cogió Kozbi a la negra y trajo a Zerah el pánico. Y se fueron Šequer y Kozbî contentos porque cavaron una fosa ante Zerah. Hicieron planes sobre el dinero que habían reunido y fueron a esconderlo. Quedó Zerah con Rispa bat 'Ayá desnuda. Y sucedió que entre tanto salió el sol y él cojeaba del muslo. He aquí que Rispâ estaba en lugar de la cierva libre...

Zerah cae en la desesperación cuando se da cuenta de la trampa en la que ha caído. Sus camaradas misóginos acuden en su ayuda y se decide darle el divorcio a la mujer de Zerah.

\footnotetext{
${ }^{28}$ La colina de los prepucios, Jos 5,3.

29 , op. cit., p. 16.

${ }^{30}$ Cf. Jr 18,20.

31 א.מ. op. cit., p. 17.
} 
La intermediaria es, en esta obra, una mujer que se define por sí misma. Kozbî habla, piensa y nos explica sus proyectos. Sus enemigos la definen como una hechicera y adivinamos la insinuación de que es mala porque es sabia, y es sabia por sus sortilegios y fornicaciones. El significado de su nombre nos dice que había heredado la habilidad del engaño.

Cuando Kozbî habla con Zerah utiliza las Escrituras con el acierto de un sabio. Zerạ̣ también las utlizará para contestarla, pero necesita ayudarse de insultos. No olvidemos que estamos en la época de los debates religiosos públicos entre judíos y cristianos. Así Kozbî aportará citas a favor de la mujer y Zerahl las aportará en contra. Este libro despertó el interés de los escritores judíos por la polémica a favor y en contra de la mujer. Poco después de su aparición, se escribieron otras obras hebreas en las que se defendía la virtud de la mujer ${ }^{32}$.

Como mujer, Kozbî se siente solidaria con el resto de las mujeres y se levanta como cabecilla entre ellas. Pero ella misma está casada y no expresa ninguna queja contra su marido, que la acompaña y la ayuda. Su lucha no es contra los hombres en general, sólo contra los misóginos.

La sabiduría de Kozbî no se basa solamente en las Escrituras, sino en su capacidad de comprender la debilidad de Zerah: su miedo a las mujeres.

Sabemos que es una anciana casada, pero no se nos dice su aspecto ni qué oficio tiene. Kozbî desempeña aquí la función de šadkanit porque su trabajo de mediadora tiene la finalidad de casar a Zerah, aunque no con la mujer que él piensa.

Éste es el núcleo humorístico de la obra y su autor interviene al final para explicarnos que los personajes que toman parte en ella nunca existieron en la realidad, sólo fueron creados para entretener y divertir al lector.

Contemporáneo de Ibn Sabbatay fue Yosef ben Meir ben Zabarra, médico de Barcelona que escribió el Libro de los entretenimientos y lo dedicó a Sešet Benveniste de Barcelona. Su estilo está relacionado también con el género de la maqama. El autor encadena argumentos diversos, pero eso no le impide dar independencia a

${ }^{32}$ Véanse las demás maqamas que aparecen en la versión de Haberman. 
cada uno de sus capítulos, los que une por medio de la narración del viaje del propio autor y su amigo ${ }^{33}$.

Zabarra dedica parte de su libro a las discusiones sobre si es o no buena la mujer para el hombre, y al final del capítulo XII nos cuenta el ejemplo de La lavandera y el demonio para demostrarnos lo malas que son las mujeres.

El amigo con el que viaja el protagonista del libro, 'Enan, resulta ser nieto del demonio Asmodeo. Con él llega a una ciudad donde ya estuvo en otra ocasión y le cuenta a su amigo lo que le ocurrió allí: pasados varios días, la abandonó entristecido, sus habitantes eran tan buenos y pacíficos que no pudo hacer allí nada malo. En las puertas de la ciudad, 'Enan se encontró con una mujer que estaba lavando en el río. La saluda y le cuenta el motivo de su tristeza. Ella se ríe de él y le asegura que si tiene la paciencia de esperar, ella volverá con mejores resultados. La moraleja está clara: las mujeres son peores que demonios.

La lavandera decide empezar como mensajera de la discordia entre dos jóvenes esposos que viven en la ciudad. Y con la excusa de buscar ropa sucia que lavar por las casas, entra en una y así le dice a la esposa:

... כי כצאתי עתה מביתי ראיתי אישך יוצא מבית זונח אחת...

... Porque cuando ahora salí de mi casa, he visto a tu marido que salía de la casa de una prostituta...

La joven cree la mentira y, como es natural, se entristece. La lavandera aprovecha:

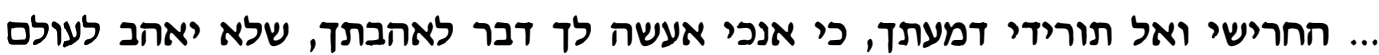

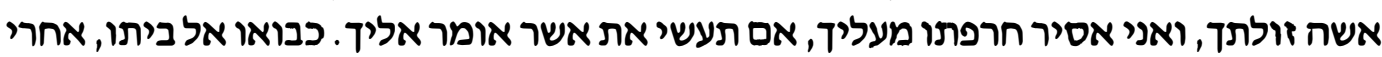

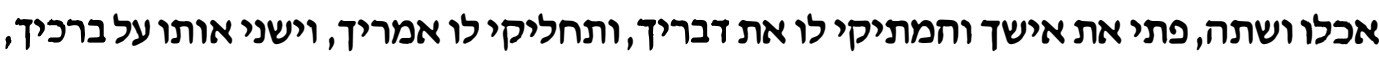

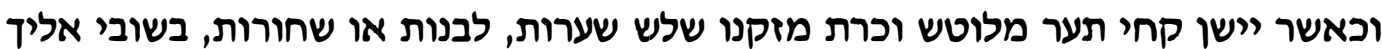

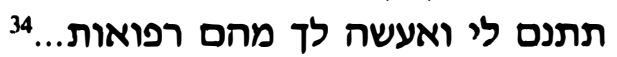

... Cállate y no derrames tus lágrimas, pues voy a hacer algo por tu amor de modo que él no quiera nunca a otra mujer más que a ti. Yo arrancaré su afrenta de ti, si haces lo que yo te diga: cuando vuelva a casa, después de que haya comido y bebido, seduce a tu marido; haz dulces para él tus palabras, suaves tus dichos; adormé-

33 PAGIS, op. cit., pp. 217-218.

34 , op. cit., p. 139. 
celo sobre tus rodillas $\mathrm{y}$, cuando esté dormido, coge una navaja afilada y corta tres pelos de su barba, blancos o negros. Cuando yo vuelva a ti dámelos para que te haga un remedio con ellos...

La lavandera espera al marido y le dice en ausencia de su esposa:

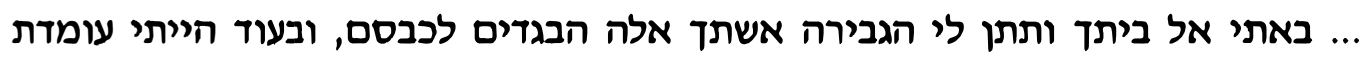

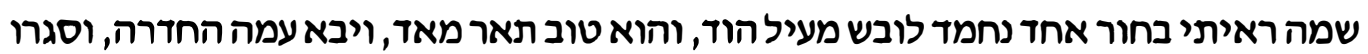

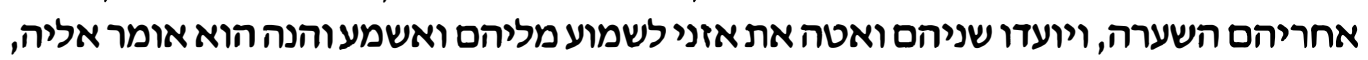

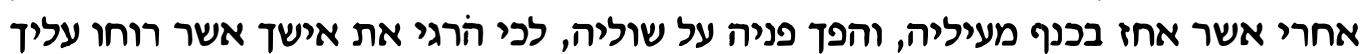

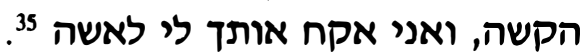

... He ido a tu casa y me ha dado la señora, tu mujer, esta ropa para lavarla. Mientras yo permanecía allí, he visto a un joven encantador que vestía una túnica magnífica. Era de rostro muy hermoso. Entró con ella en su habitación y cerraron la puerta tras de ellos. Cuando se quedaron juntos agucé el oído para oír sus palabras y escuché. He aquí que le decía a ella, después de asir el borde de sus vestidos y volver su rostro sobre su falda: Ve y mata a tu marido, pues su espíritu se ha endurecido contra ti. Yo te tomaré por mujer.

El resultado es que la esposa intenta cortar los tres pelos de la barba de su marido, quien se hace el dormido. Cuando el marido siente la navaja cerca del rostro, se levanta rápido y teniendo por cierto que ella quiere matarlo, apuñala a su mujer. Entonces los familiares de la mujer matan al marido. Como resultado de la lucha entre las dos familias, cayeron doscientas veinte víctimas en la ciudad.

La intermediaria de Zabarra no coincide con la definición de casamentera ni con la de alcahueta. Su finalidad es precisamente desunir una pareja y sin más motivos que el de enorgullecerse de saber hacer el mal mejor que el propio demonio.

No se hacen descripciones de su aspecto exterior, pero se alude a su oficio de lavandera. Nos interesa aquí su actuación como mensajera, que se basa en el buen conocimiento de los celos humanos, los cuales manipula para producir sentimientos de inseguridad entre la pareja. Sabe que el miedo les impedirá sincerarse $y$, sin ningún escrúpulo, les dará a ambos información falsa y opuesta, con el fín de separarlos.

\footnotetext{
35 י. דאווידזאן ibid., p. 140.
} 
A principios del siglo XIII, el escritor judío Al-Ḥarizi sale de Sefarad para emprender un largo viaje por Oriente. Cuando regresa escribe un libro: Tahkeĕmôní, muy influenciado por las cincuenta maqamas del autor árabe Al-Hariri.

La obra, escrita en lengua hebrea y en prosa rimada, incluye abundantes versos y citas bíblicas. Cada maqama es un capítulo y un tema independiente. La unidad de la obra se consigue por medio de los personajes que se encuentran en cada capítulo y uno le cuenta al otro una de sus aventuras. Ésta es la única maqama escrita en lengua hebrea que se ajusta al modelo de la maqama clásica árabe ${ }^{36}$.

Los dos protagonistas son Heber ha-Qênî ${ }^{37}$, pícaro y trotamundos incapaz de permanecer demasiado tiempo en un mismo lugar, y Hêman ha-'Ezraḥ̂ ${ }^{38}$, hombre sedentario y lleno de sentido común.

En la sexta maqama aparece el personaje de la intermediaria. Los dos protagonistas se encuentran y Hêman ha-'Ezrahî le propone a su amigo contraer matrimonio, como primer paso para fijarlo a un lugar. La reacción de Heber ha-Qênî es de espanto y asegura que no se acercará más a una mujer después de lo que le acaba de pasar.

ואני מתחלך במדינח. מעבר לעבר ומפנח לפנח. וחנח אשח זיח זקנח. ברע תמונח.

וצורח משנח. כאלו חזמן גנבח מן חשרד לעבר ומפח לחיות לו למנח

Me paseaba yo de un lado a otro y de una esquina a otra de la ciudad. $\mathrm{Y}$ he aquí una mujer anciana de mal aspecto y rostro extraño. Como si el tiempo la hubiera arrebatado a los diablos para que fuera su ración de comida.

Al-Harizi nos proporcionará expresiones claves para que entendamos que se trata de un personaje negativo. Uno de ellos es el nombre de esta mujer mayor, de aspecto inquietante: Sifnâa ${ }^{40}$.

ויקרא שמח שטנח. תמונתח כבת חיענח. ואחריתח מרח כלענח. פניח בצעיפח

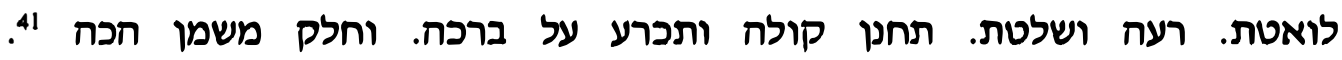

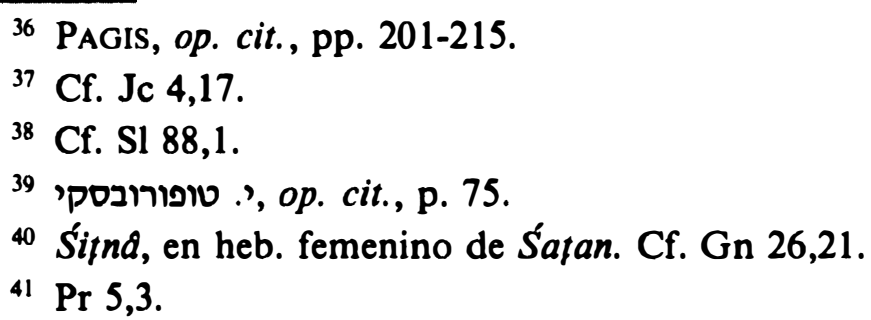


הצוף בלשונה. וסם המות בגרונה. מתנהגת בחסידות. והיא בת נעות המתות המרדות.

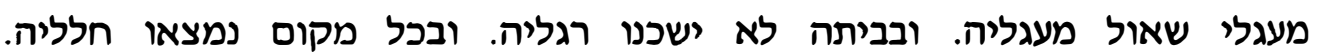

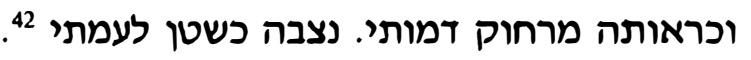

Y era su nombre Siţnâ. Su figura era como la del avestruz y su fin amargo como el ajenjo. Con su velo cubría su rostro, es mala y dominante. $\mathrm{Su}$ voz pide misericordia y caerá de rodillas. Su paladar es más suave que el aceite y en su lengua hay miel, pero la droga de la muerte está en su garganta. Se conduce con piedad pero es hija de la perversión. Sus caminos son sendas del Š̆̌ôl. Sus pies nunca paran en su casa porque en todo lugar encuentran víctimas. Cuando me vio de lejos, como Śatán se presentó junto a mí.

Sitnâ se dirige a Heber ha-Qênî como una madre halagadora:

בני בני יאריך אלחים חייך וישמר זחר לחייך ויהיה לעד רענן פריך ראיתיך

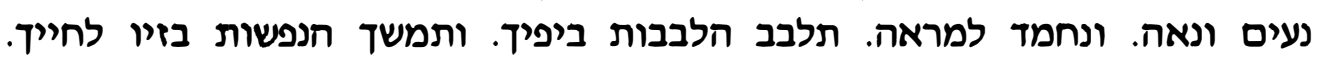

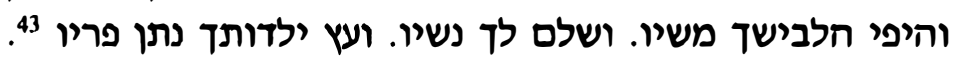

¡Hijo mío! ¡Hijo mío! ¡Que Dios alargue tu vida, guarde el brillo de tus mejillas y sea tu fruto siempre fresco! ¡Te vi tan hermoso, elegante $y$ de aspecto encantador! Con tu hermosura, los afectos aumentas y con el realce de tus mejillas, atraes las almas. La belleza te revistió de obsequios con su seda y te pagó sus deudas. El árbol de tu infancia dio su fruto.

El nivel social de nuestro protagonista interesa a Siţnâ y se dispone a manipularlo:

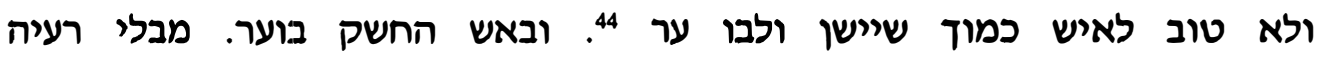

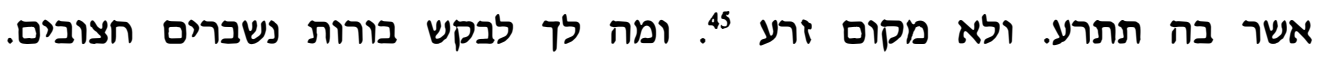

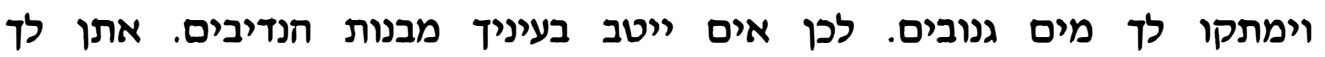

אילת אהבים 46.

Pero no es bueno que un hombre como tú duerma y tenga el corazón despierto y con el fuego del deseo se queme. Sin una amiga con la que acoplarse, ni un lugar donde pueda echar simiente. ¡Y qué ganas con cavar cisternas agrietadas! ¿Acaso te podrán endulzar

\footnotetext{
42 , op. cit., p. 75.

43 י. ibid.

44 Cant 5,2.

45 Num 20,5.

46 , op. cit., p. 75.
} 
aguas robadas? Por eso, si te gustan las hijas de los nobles yo te proporcionaría una gacela de amor.

La manipulación de Sítnâ se basa en la promesa del dinero y la belleza de la novia, que conseguirá el que se case con ella. Igual que Kozbî en el libro de Šabbatay. La descripción sensual, incitante y obscena que hace la anciana de la novia deja a Heber ha-Qênî tan aturdido que ya no sabe lo que hace:

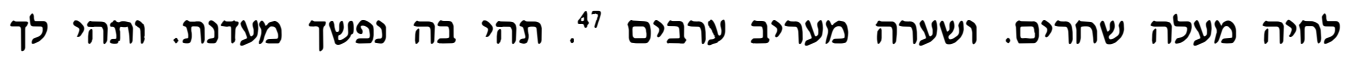

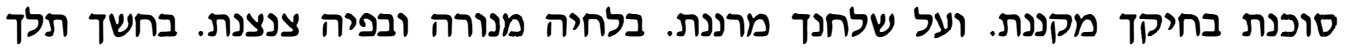

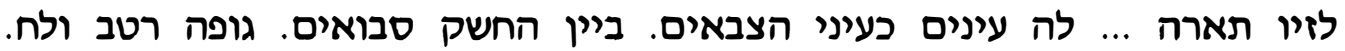

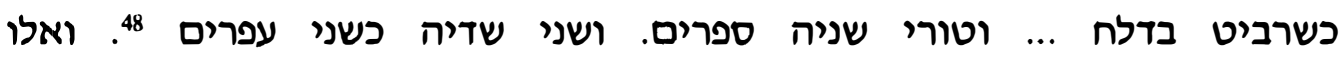

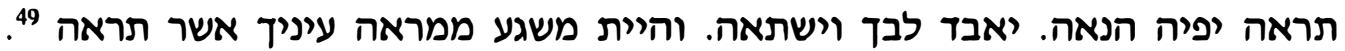

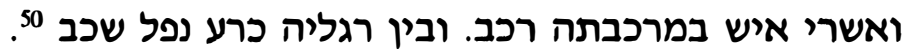

Su mejilla sobrepasa la aurora y su cabello oscurece el crepúsculo. ¡Esté con ella tu espíritu exquisito y que ella te cuide! Que ella anide en tu seno y a tu mesa cante. Que en sus mejillas esté la luz y en su boca el frasco de perfume. Al brillo de su imagen podrás caminar entre tinieblas ... Tiene ojos como de corza empapados en el vino de la pasión; su cuerpo es fresco y tierno como una varilla de cristal ... La hilera de sus dientes es como zafiros y sus dos pechos como cervatillos. Si vieras su elegante belleza, se perdería y se asombraría tu corazón y te volverías loco de ver lo que verán tus ojos. Feliz el hombre que cabalgue en su carruaje y entre sus piernas se doblegue, caiga y yazga.

Éste es un buen momento para interrumpir la descripción y recordar al joven los móviles por los que ella trabaja:

אבל כל חרוצח בח לחתחתן. אלפים כסף יתן.

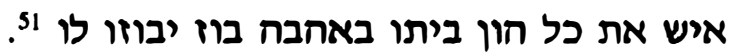

Pero todo el que quiera con ella casarse que pague dos mil dineros. Poca cosa será dar por ella todo su dinero y fortuna, si uno diera por amor toda la hacienda de su casa, eso le parecería como nada.

\footnotetext{
${ }^{47}$ Expresión tomada de la oración diaria de la tarde 'arbît.

48 Cant 4,5.

49 Dt 28,34.

so טופורובסי., op. cit., pp. 75-76.

51 Cant 8,7. טופורובסקי טובסי., op. cit., p. 76.
} 
Heber ha-Qênî se da cuenta de que todavía no ha visto a la muchacha y le dice a Śitnâ que si pudiera verla, no dudaría en casarse con ella. Pero ella sabe muy bien cómo inspirar confianza:

חלילה חלילה. אם ארמה אותך ואם אכשילה. ואם אפת אפתה אותך במלי

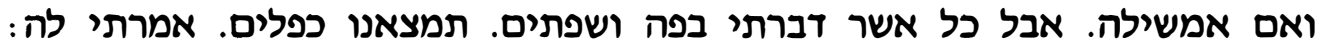

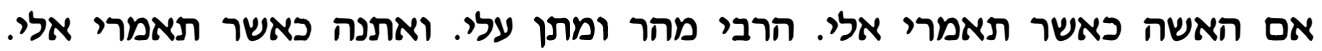

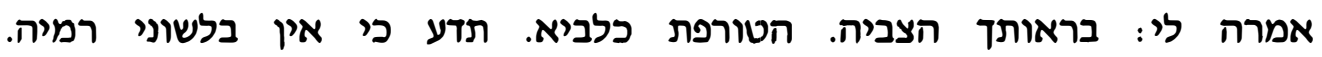

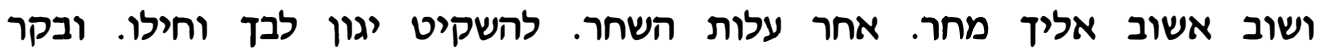
וידע הי את אשר לוב אשיד משר

¡Que Dios me castigue si te engaño o estorbo, si te seduzco con mis palabras o si te cuento patrañas! Pues todo lo que dije con boca y labios, te lo encontrarás el doble. Y le dije a ella: Si la mujer es como me has dicho, fijame la dote y los regalos, y daré lo que me digas. Me respondió: Cuando veas la gacela que desgarra como un león, sabrás que no hay engaño en mi lengua. Yo volveré a ti mañana, después de la subida de la aurora, para tranquilizar la inquietud de tu corazón y su angustia iY por la mañana Dios proveerá!

El joven no consigue dormir aquella noche:

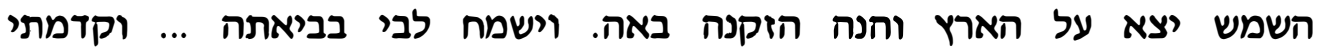

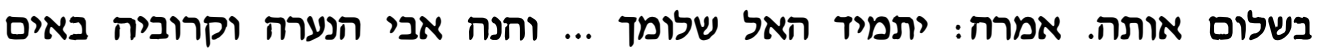

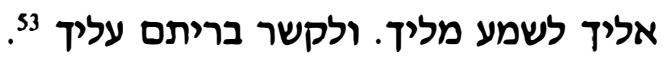

Apuntó el sol sobre la tierra y he aquí que vino la anciana. Y se alegró mi corazón con su llegada ... La saludé y me dijo: ¡Que Dios te conserve la paz! ... He aquí que el padre de la muchacha y sus parientes vienen hacia ti, a escuchar tus palabras y a sellar contigo alianza.

Heber ha-Qêni, aturdido por el padre y los testigos de la joven a quien todavía no ha logrado ver, firma el contrato matrimonial. La boda se celebra y cuando todos se van a sus casas y los dos se quedan solos, el novio descubre que la novia es fea y además no tiene dinero. Entonces el joven burlado coge tres varas y tapándole la boca a su horrible mujer para que no grite, la golpea en la espalda hasta romper las varas y hacer brotar la sangre. Asustado por lo que ha hecho, huye de la ciudad, y así se termina el capítulo.

\footnotetext{
52 י., ibid., p. 76.

53 י., ibid., p. 77.
} 
La šadkanît en este relato no es una mujer culta como en la obra de Sabbatay e incluso se expresa con obscenidades. El autor la describe como una anciana de mal aspecto y la relaciona con Śatan por el hecho de utilizar expresiones piadosas de forma hipócrita ${ }^{54}$. Sítnâ se define a sí misma por su comportamiento. Con gran habilidad psicológica capta las dudas y los deseos de su víctima y las sabe manipular hasta conseguir el objetivo de su trabajo: el dinero.

Hemos presentado tres modelos de intermediaria que aparecen en la literatura hebrea de la Edad Media escrita en la Península Ibérica. Las características de Kozbî y Sittnâ corresponden a las descritas en la quinta variedad del personaje. Por el contrario, La lavandera, tiene las características de la tercera variedad.

No podemos afirmar que los modelos Kozbî y Sithâ sean iguales por el hecho de que ejecuten la misma acción. La primera, siente a las mujeres en peligro y quiere hacer caer al hombre misógino en la trampa para salvarlas, mientras la segunda sólo quiere dinero.

Sin embargo, hay que señalar que ambas šadkanîyôt utilizan los conocimientos de las Escrituras o las expresiones piadosas de forma hipócrita con la finalidad de atraer la confianza de sus víctimas.

En cuanto a La lavandera, ya señalamos que es una intermediaria en sentido opuesto, no está interesada en unir al hombre con la mujer sino en separarlos. Pero también ella atrae la confianza de los esposos con pretextos morales y religiosos.

Hay que señalar que la aparición de la intermediaria en las tres obras se justifica dentro del marco de las discusiones retóricas tan del gusto de la Edad Media, sobre si la mujer es buena o no. Nuestras tres intermediarias representan una seria amenaza para el hombre, puesto que con su inteligencia son capaces de engañarlo.

Curiosamente, los tres autores fueron contemporáneos. Incluso se cree que Al-Harizi visitó a Sabbatay cuando era ya anciano, en uno de sus viajes. Esto justificaría el hecho de que se encuentren tantas expresiones iguales en las dos creaciones: las maqamas del primero y La ofrenda de Yehudah.

La tercera y quinta variedad de la intermediaria aparecerán tiempo después en su versión castellana, salvando las diferencias. $L a$

${ }^{54}$ Ibn Hazm alude en su obra al uso hipócrita de signos piadosos por parte de la intermediaria cuando la describe con rosarios. Véase la nota 5. 
lavandera de Zabarra parece que fue conocida por Don Juan Manuel y que fue la fuente de su falsa beguina ss.

Los modelos de Sítnâ y Kozbî están mas próximos a los de Trotaconventos y La Celestina, teniendo en cuenta más sus actuaciones de mensajeras que la finalidad que persiguen. Pero es evidente que estamos hablando de diferentes modelos de intermediaria: Sițnâ y Kozbî son casamenteras, mientras que Trotaconventos y Celestina son alcahuetas.

El Libro del Buen Amor se creyó durante bastante tiempo influido sólo por fuentes latinas ${ }^{56}$. Pero las investigaciones realizadas por M. R. Lida de Malkiel y por Américo Castro sobre esta obra ${ }^{57}$ comenzaron a apuntar hacia otras influencias literarias, concretamente, las de las literaturas árabe y hebrea, llegando a la conclusión de que se trataba más de una imbricación de versiones orientales y occidentales difíciles de delimitar, que de una sola línea de influencia ${ }^{58}$.

\footnotetext{
3s Así lo defiende Ayerbe-Chaux en contra de González Llubera. Cf. AyerbeChaux, op. cit., p. 19.

56 Principalmente por el Arte de Amar de Ovidio y por las obras anónimas medievales Pamphilus y De vetula, escritas en latín.

57 M. R. LIDA DE MALKIEL, Juan Ruiz: selección del Libro del Buen Amor y estudios criticos, Buenos Aires 1973, pp. 208-226 y A. CASTRO, España en su historia, cristianos, moros y judíos, Buenos Aireș 1948, pp. 371-469. Véase también D. Gonzalo MaEso, Manual de historia de la literatura hebrea, Madrid 1960, p. 536.

${ }^{58}$ Cf. F. Rico, op. cit., pp. 301-325.
} 


\section{RESUMEN}

Se presenta en este artículo la figura de la intermediaria (̌̆adkanît) en la literatura hebrea medieval escrita en la Península Ibérica. Se describe el aspecto y la conducta de tres intermediarias hebreas: 1) Kozbî, en el libro de Yehudah Ibn Šabbatay, Minhat Yèhûdâ, sône’ ha-našìn, 2) Śitnâ en la sexta maqama de Al-Harizi, 3) La

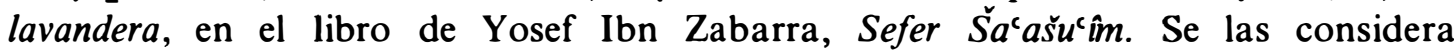
precedentes literarios de las intermediarias castellanas Trotaconventos y Celestina.

\section{SUMMARY}

Discussion of the character of the female matchmaker (šadkanit) and her qualities in medieval Hebrew Literature of the Peninsula. Reference is made to three matchmakers: 1) Kozbî, in the book Minhat Yěhûdâ, śône’ ha-našim, by Yehudah Ibn Šabbatay, 2) Sitinâ in Al-Harizi's sixth maqama, 3) The demonic woman, The

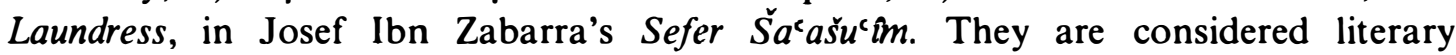
precedents of the Castilian matchmakers Trotaconventos and Celestina. 